\title{
Retrospective survey on drugs seized in Niger from 2013 to 2016 and state of the art on drug analysis and detection techniques
}

\author{
Salifou Karimoune Fadjimata
}

Departement of Chemistry, Abdou Moumouni Universiiy. BP 10662, Niamey (Niger)

\begin{abstract}
Adamou Rabani
Laboratoire Matériaux, Eaux et Environnement (LAMEE), Departement of Chemistry, Abdou Moumouni Universiiy. BP 10662, Niamey (Niger)
\end{abstract}

\section{Zangui Hamissou}

Faculty of agronomy, Abdou Moumouni University, BP: 10960 Niamey (Niger

salifoufadjimata@gmail.com

\begin{abstract}
Drug is a substance, which trouble brain. One of the reasons for juvenile delinquency is drug use. The present work is a retrospective study based on seizures of drugs made by the Niger courts and. Evaluation of the drug utilization by people according to the statistics of drug seizures from 2013 to 2016 of the Central Office for the Suppression of Illegal Traffic in Narcotics (OCRTIS). According to the statistics of drug seizures from 2013 to 2016 of the Central Office for the Suppression of Illegal Traffic in Narcotics (OCRTIS). Nine (9) types of drugs belonging to six (6) families were seized in Niger including: Amphetamines, Cannabis, Crack, Cocaine, Diazepam, Ephedrine, Heroin, Methamphetamines and Tramadol. These come from all countries bordering Niger but also from East Africa and Central Africa and the data gathered was analyzed using MS Excel. It should be noted that the percentage of those charged varies according to age group whose: the under 18 's are $6 \%, 59 \%$ are between 18 and 29 years, $25 \%$ are between 30 and 39 years, the 40 years and over are $10 \%$. So most of the people which have been arrested are minors between 18 and 39 years old. In addition, it is necessary to mention $2 \%$ of women against $98 \%$ of men in the said sale and consumption. If the number of seizures increases each year, the possibility of drug consumption by its users would also grow and highlights important diseases related to their consumption. Thus, the more appropriate implication of the blood and urine tests of these drug users.
\end{abstract}

Keywords. Drugs, retrospective Survey, Niger 


\section{Contexte}

According to WHO, Drug utilization research is defined by as "marketing, distribution, prescription and use of drugs in a society, with special emphasis on the resulting medical, social and economic consequences". Drug utilization evaluation (DUE) or drug utilization review (DUR) is an essential part of pharmaco-epidemiological studies (Basavaraju, Praveen, 2016) Since prehistory, drugs have been used for a variety of reasons: religion, health, pleasure, and commerce. (ONUDC, 2015). A drug is any synthetic or natural compound that is capable of altering one or more neuronal activities and / or disrupting neuronal communications, once absorbed or adsorbed (Bawa, 2016) (ONUDC, 2015). It comes in several forms (Figure 1) namely: powder, capsules, tablets, crystals, rocks, leaves, oils, seeds, glues, solvents, liquids and blotters. (Bawa, 2016) (Gendarmerie Royale du Canada, 2018) (UNODC, 2012). Man consumes drugs in order to modify his physiological or psychic functions, his physiological reactions and his states of consciousness. Several reasons led the user to take it: curiosity, imitation, poverty, assertiveness, academic success, family problems, health, religion, commerce, pleasure (Gilles, 2010) etc. It is used by several modes of administration, which are oral aspiration, ingestion, inhalation, injection, the prized and the topical (Gilles, 2010) (Gendarmerie Rogale du Canada, 2015). Indeed, according to the types of consumption that are the recreational use, the abuse or harmful use, the dependency; some drugs can lead to physical or psychological dependence (Gendarmerie Royale du Canada, 2015) (Gilles, 2010) (Sante, 2013) and give the user several sensations that are grouped into three categories: relaxants, stimulants and disrupters (Bawa, 2016) (Gendarmerie Royale du Canada, 2015). This is why the term "drug" essentially covers two aspects: the nature of the biological effects that it induces on the one hand and, on the other hand, the relationships that the user has with it. The consequences of its use are: addiction, dementia (madness), depression, school failure, contamination of STI / HIV / AIDS, hepatitis C, delinquency, violence (aggression), crime, rejection social (marginalization), theft, prison, suicide, death ... (ONUDC, 2016-2017) (Bawa, 2016 ) in $201729.5 \mathrm{M}$ people suffer the consequences of its use.

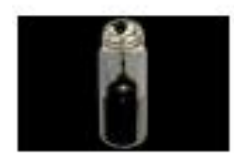

Oil

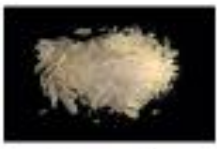

Crystal

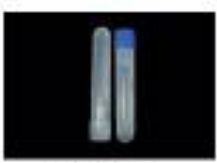

Liquid

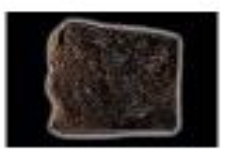

Résine

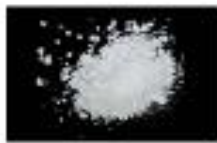

Powder

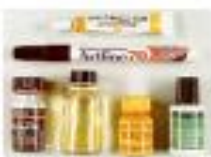

Solvents

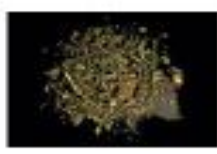

Grass

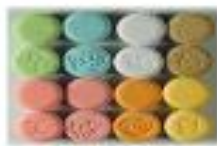

Tablet

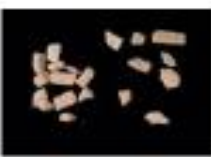

Rock

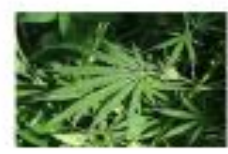

Leaf

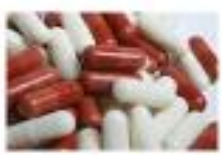

Capsules

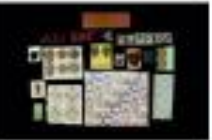

Blotting-paper

Figure 1: Some pictures of the different forms of drugs 


\subsection{The production and /or consumption of drugs is region-specific.}

\section{1.1. The producing countries are:}

America produces $80 \%$ of cocaine (COC) in Mexico, Peru, Bolivia and Colombia. In the latter country, drug production is the informal "New economy", illegal but tolerated. SouthWest Asia more specifically in Afghanistan and South-East Asia in the LPDR (Lao People's Democratic Republic) region and Myanmar with 67\% of opiates (MTD) production. Oceania, particularly in Australia with 47\% of opiates (MTD) (Deller et al, 2003) (Chavanne, 2012) (UNODC, 2004, 2010)

\subsubsection{The consuming countries are:}

Europe consumes 80 percentage of Cannabis (THC) in the following countries: the United Kingdom, Spain, Italy, Germany, France, the Czech Republic, Austria and Hungary (ONUDC, 2010, 2015) (Institut Espagnol d'Études Stratégiques (IEEE) et Institut Militaire de Documentation de l'Évaluation et Prospective (IMDEP), 2013). Africa, mostly West Africa consumes Cocaïne (COC), methamphetamine (MOP), Amphetamine Substances (STA) and Cannabis (THC) including the Maghreb and the neighboring countries of Guinea called "Cocaine Coast" (Isidore, 2012) (Observatoire Géopolitique des Drogues, 1994) (Pautremat, 2013) (Berghezan, 2012). The figure 2 shows us how drugs are transported from Europe to Africa, passing through West Africa to reach Niger.

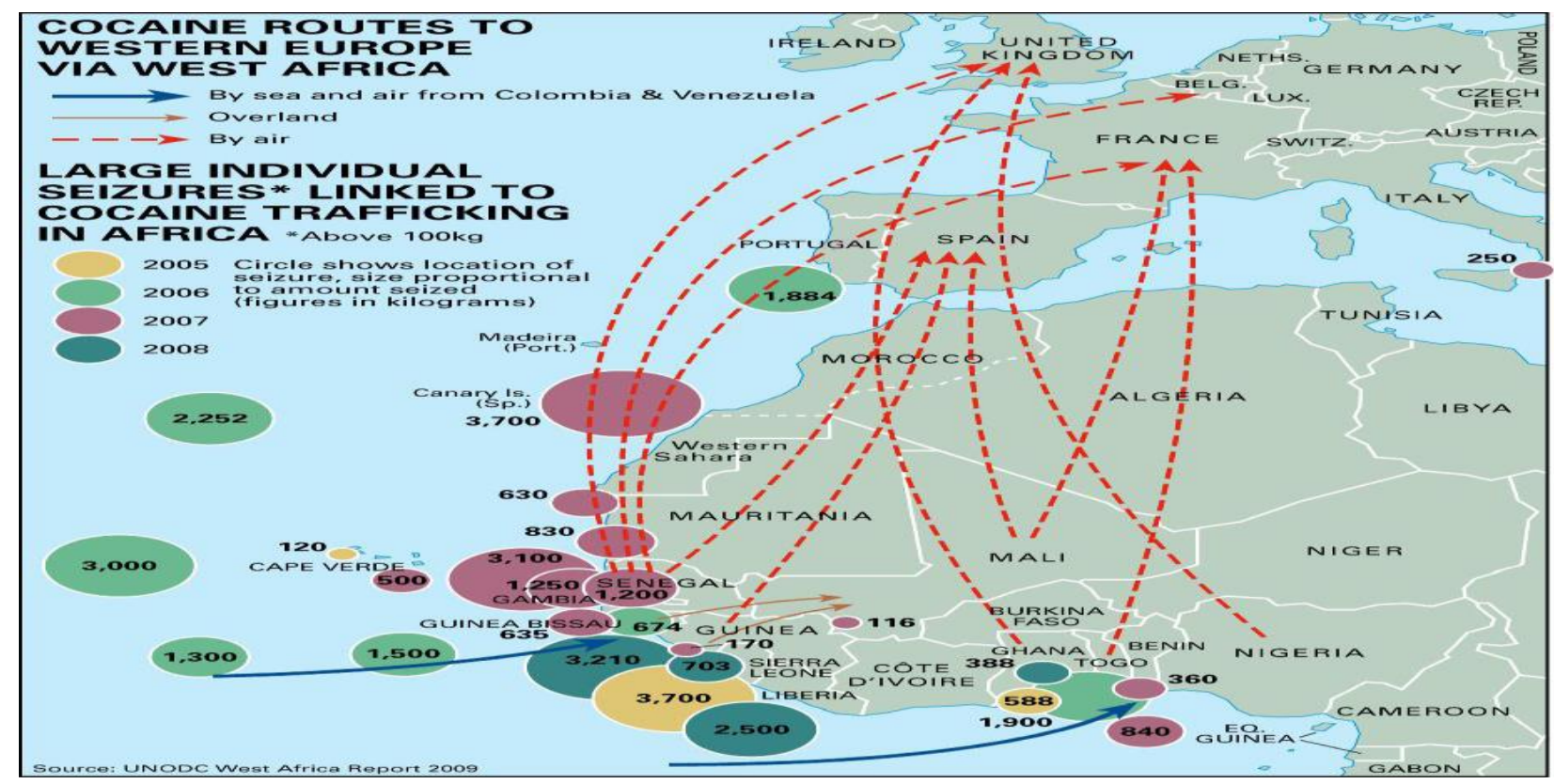

Figure 2: Roads and cocaine seizures in West Africa (GRIPS, 2012)

Indeed, the Drug Control Coordination Commission (CCLAD) in Niger is seizing (one ton of illicit drugs and products in 2012) and incinerating large quantities of drugs seized: $5 \mathrm{~kg}$ of cocaine, $22.8 \mathrm{~kg}$ of cannabis, 120,000 tramadol tablets, 32 tablets of diazepam, $378 \mathrm{~kg}$ of Indian hemp and 700.000 tablets of amphetamine (actuniger.com, 2016). Trafficking routes of drugs, which come on Niger, are shown in figure 3. 


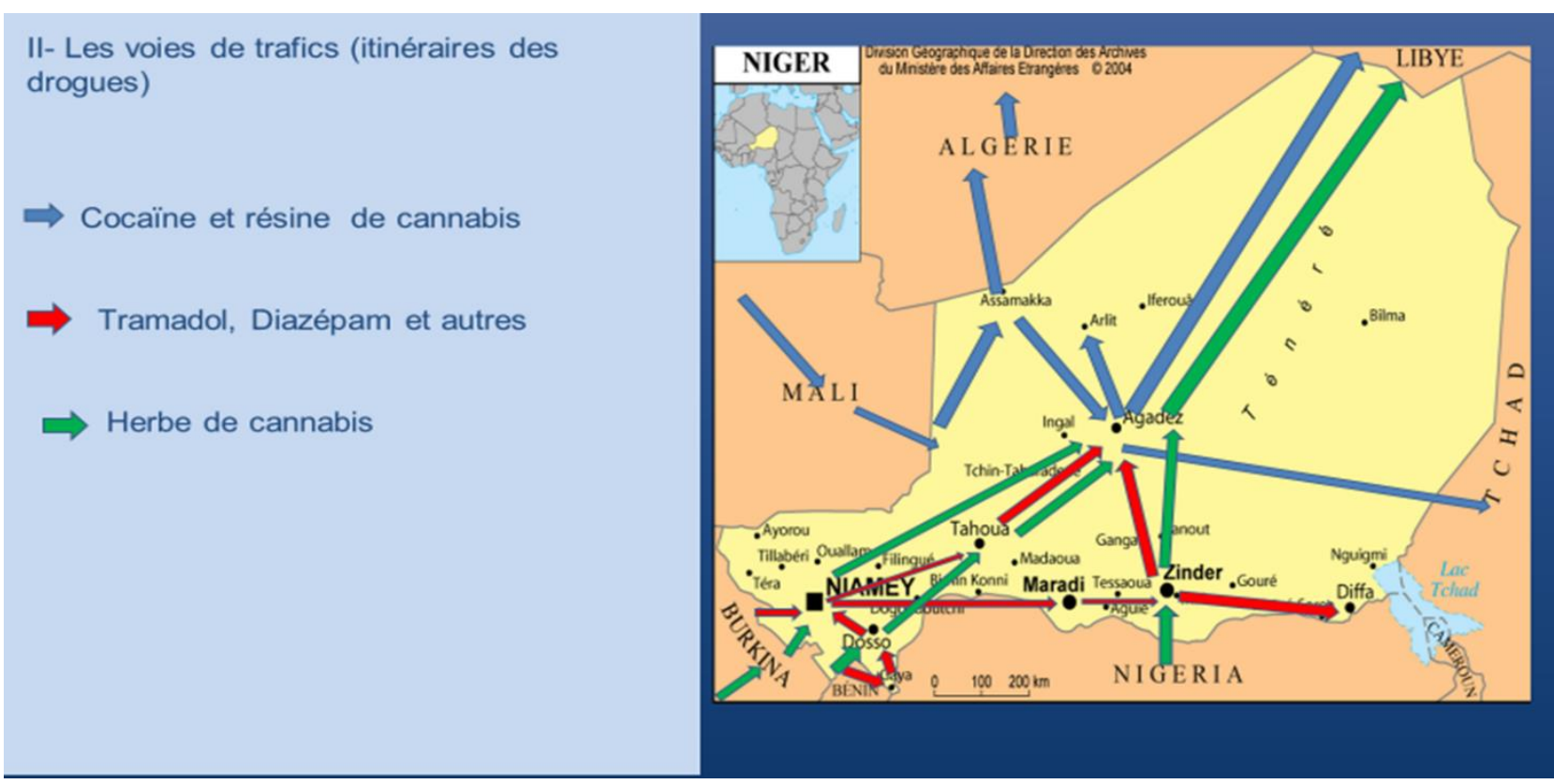

Figure 3: Roads of drug trafficking in Niger (OCRTIS 2017)

1.2. The different dosing techniques used for the detection of drugs and their metabolites, several analytical techniques are used in case of doubt of a user.

1.2.1. Qualitative analyzes that are inexpensive and determine the presence or absence of the active ingredient of the drug and / or its metabolite: Check Drugs; the Thin Layer Chromatography (TLC); Immunoenzymatic; as for Immunoassay after hydrolysis gives the concentrations of different metabolites (Jatlow, 1988) (Cohen et al, 2004)

1.2.2. Quantitative analyzes that are certainly expensive and give most of the concentration of the main metabolite, can use the remains of bullet wounds with minimal amounts in aqueous or wet medium and does not require pretreatment; these are: High-Pressure Liquid Chromatography(HPLC); Radio Immuno Assay (RIA); Raman Spectroscopy and Chemometric Methods (RSCM). Their disadvantage is that you have to wash several times and there is a risk of contamination. When to the Gas Chromatography (CG); Gas Chromatography/Mass Spectrometry (GC / MS); Liquid Chromatography/Mass Spectrometry (LC / MS). They give the concentrations of all the metabolites and other substances present. These techniques have good linearity, precision and sensitivity. (Jatlow, 1988) (Ryder et al, 2000) (Schiffer, 2005) (Takaichi, 2000) (Yilmaz, Erdem, 2015).

1.2.3. Technical extraction are less expensive with ease of operation, low detection limit with dynamic range and ordinate. These techniques are fast, efficient, accurate, linear and simple with good reproducibility, sensitivity, and ease of operation. These are Solid Phase Extraction; the Dispersive Liquid-Liquid Microextraction/Gas Chromatography/Mass Spectrometry (DLLME/CG/MS), the Supercritical Fluid Extraction / Gas Chromatography / Mass Spectrometry (SFE/GC/MS) which give good yields. The advantage is that there is no contamination and deproteinization phase but mostly uses very little water. For Liquid Phase Extraction, it is necessary to make several purifications, thus a decrease of the phase to be reprocessed. (Gaillard, 1996) (Takaichi, 2000), (Richeval et al) (Habibollahi, 2014) (Mahado et al, 2016). 


\section{Methodology}

At first, list all the drugs consumed in the world and highlight in a table their families and groups including half-lives and threshold concentration seizures. Identify the common drugs used in Niger and list those routinely seized and consumed in Niger through statistics of seizures from OCRTIS (the Central Office for the Suppression of Illegal Traffic in Narcotic Drugs) in Niger. Highlight the number of people arrested by gender and the percentage required. Highlight the number of people arrested per age group and their percentage. To highlight those seized by the courts of Niger in another table with their corresponding names in national languages (in Hausa and Zerma). Our review of the literature begins with the classification of drugs by family and type (Table I). So far, no publications have been made on drugs, although important seizures of tramadol and cannabis resin have been made (June 2018 AIRCOP Task Force in Niamey, Niger assists in the seizure of 2,5 tons of cannabis and 2013 Tramadol trafficking in Niger). A search for different search-engines (Google chrome, Google Scholar Bing, and Yahoo) was the result of the Niger region, located in the heart of the Sahel-Saharan strip and having $1267000 \mathrm{~km}^{2}$ (Bermus, Hamidou, 1981) of area of which three quarters are desert, is mainly a transit zone for various drug trafficking, for which the desert has become a favorite zone of armed banditry. Highlight the most commonly used drugs.

\section{Results and discussion}

\subsection{Survey Review of Drugs in the world}

A total of 72 drugs belonging to 11 families as well as their half-lives and abbreviations are listed in Table 1.were reported in the literature as being used all over the world but 9 drugs belonging to 6 families by the Nigerien population to cause many unusual behavior. Most of them cause foolish to drugs users. So these families and different kind of drugs are summarized in Table 2 included their names in national languages. Two (2) species of Opiates MTD or MTP; followed by 3 species of Methamphetamine MOP, MOR or OPI; one specie of Cannabis (THC); 1 specie of cocaine (COC); one specie of Benzodiazepines (BZE or BZO); and one specie of Amphetamine (AMP).

Table 1: Classification of different types of drugs used around the world

\begin{tabular}{llcll}
\hline Drugs families & Abbréviation & Types & $\begin{array}{l}\text { Half life } \\
\text { Average }\end{array}$ & Détection time \\
\hline Amphetamines & AMP & 6 & $10-30 \mathrm{~h}$ & A few $\mathrm{h}-4 \mathrm{~d}$ \\
Barbituriques & BAR & 11 & $19-77 \mathrm{~h}$ & $2-4 \mathrm{~d}$ \\
Benzodiazepines & BZE ou BZO & 23 & $22-48 \mathrm{~h}$ & More than 25 d \\
Buprénorphine & BUP & 1 & $8-15 \mathrm{~h}$ & A few min-2 d \\
Cocaïne & COC & 2 & $2,5-4,5 \mathrm{~h}$ & A few h- $1.5 \mathrm{~d}$ \\
Methadones & MET (M-AMP) & 4 & $15-55 \mathrm{~h}$ & More than 5 s \\
Methamphétamines & MOP (MOR, OPI) & - & $10-30 \mathrm{~h}$ & A few h $-4 \mathrm{~d}$ \\
Opiates & MTD (MTE) & 5 & $6-30 \mathrm{~min}$ & A few min-3 d \\
Tricyclic antidepressants & TCA & 12 & A few h & $1-2 \mathrm{~d}$ \\
Cannabis & THC & 7 & $20-30 \mathrm{~h}$ & Around $24 \mathrm{~h}$ \\
Lyserg Saure Diathylamid & LSD & - & - & 5 \\
\hline
\end{tabular}

$\mathrm{d}=$ days, $\mathrm{h}=$ hours, $\min =$ minutes, $\mathrm{s}=$ seconds 


\subsection{Survey Review of Drugs in Niger}

According to the national statistics of drug seizures from 2013 to 2014 of the CCLAD and from 2015 to 2016 of the OCRTIS, Nine (9) types of drugs (Figure 2) were seized in Niger including: Amphetamines, Cannabis, Crack, Cocaine, Diazepam, Ephedrine, Heroin, Methamphetamines and Tramadol. These come from all countries bordering Niger but also from East Africa and Central Africa. (Office Central de Répression de Traffic Illicite des Stupéfiants, 2013-2016) (Figure 3).

The most used drugs in Niger are Amphetamine, Cannabis, Cocaïne, Diazepam, Ephedrine, Methamphetamine (which could only be detected in 2013), and Tramadol. In 2016, in addition to these seven (7) types of drugs are added Heroin and Crack; which will be illustrated by figure 3, which describes the evolution of seizures of drugs in Niger. (Office Central de Répression de Traffic Illicite des Stupéfiants, 2013-2016)

On the celebration of the 27th World Day against Drug Abuse and Trafficking, Mr. Marou Amadou (Minister of Justice) indicated in his speech that more than 1200 Nigeriens were arrested. "Our youth is therefore particularly affected. In fact, out of 1,254 people arrested, 1172 are Nigeriens and 892 are between 18 and 29 years old, "he said. In the same context, the minister specifies that for the first trimester there are 20 known addicts, (ie 17.9\%) and 62 cases of psychiatric disorders due to psychoactive substances (ie 5.58\%) of the 358 cases were registered. (Seydou, 2016)

Due to its very lucrative nature, the drug trade is well developed in all regions of Niger and in local markets as well, so the most affected communes (neighborhoods) are: to introduce a figure of the map of Niger illustrating the neighborhoods most affected the commune II (katako market where the sale is done in the open air, this one is called "New Colombia of Niger; the Commune III (Koira Teigui district); and the commune V (district of Haro Banda) with provenances from Benin, Burkina Faso, Ivory Coast, Mali, Togo (Office Central de Répression de Traffic Illicite des Stupéfiants, 2013-2016). Drug production and trafficking raise major problems in various policy areas: agriculture, health, education, urban violence, but also at the international level. Faced with this scourge, policies of prohibition more or less generalized were established by the States for the narcotics products (Sophie, 2016) (Lambert, 2000). 


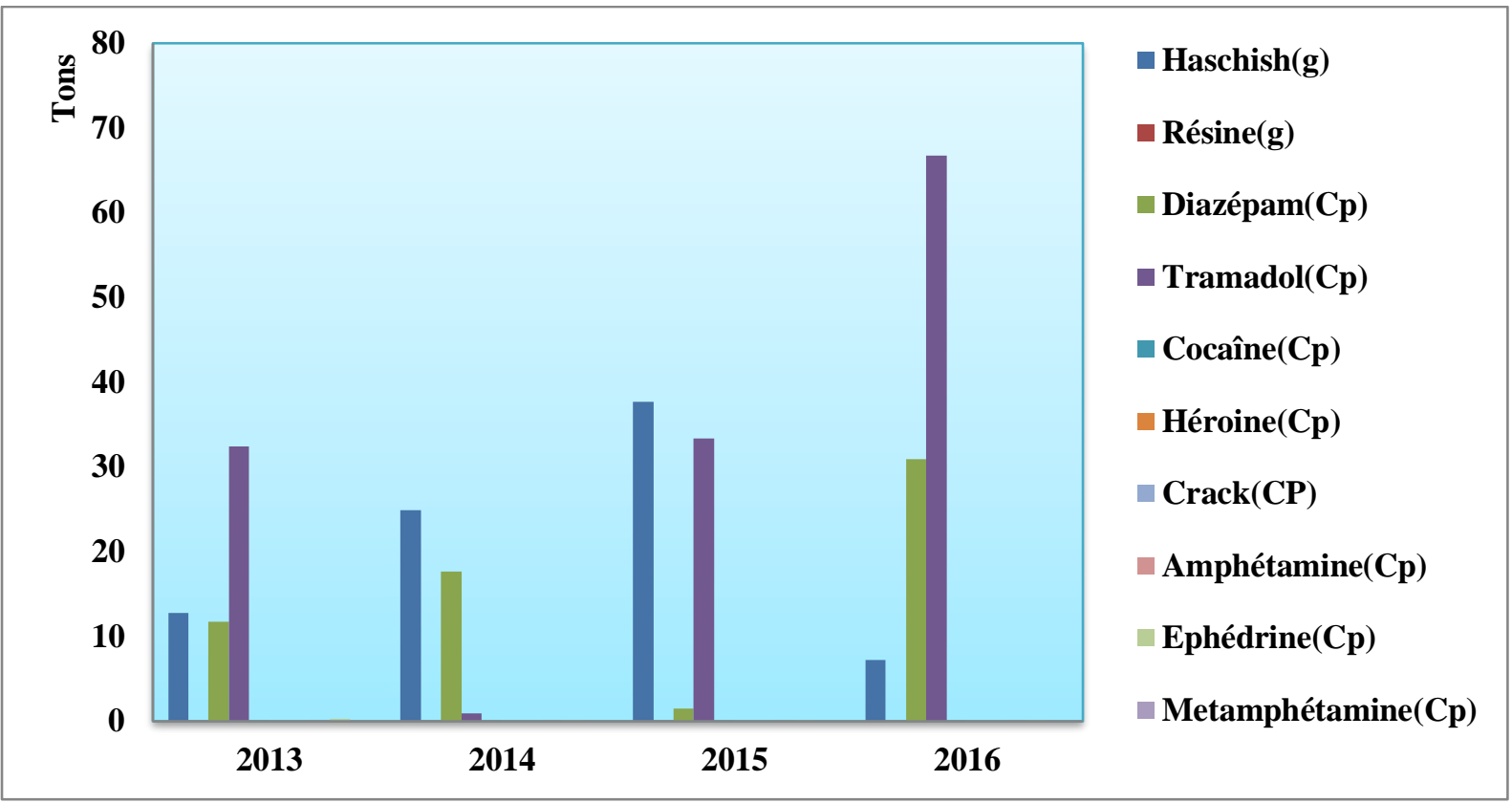

Figure 3: Evolution of drug seizures in Niger from 2013 to 2016

$\mathrm{g}=$ grams, $\mathrm{Cp}=$ tablets

Nine (9) drugs belonging to six (6) families were reported in the literature as being used by the Nigerien population for many different reasons. The most commonly used drugs are four (4) of them (four species) in order belong to the family of Opiates, Benzodiazepines which represent $50 \%$ for semi-legal drugs, Cannabis and Cocaïne (Table 2).which are distributed the other $50 \%$ for unlawful drugs.

Table 2: Different types of drugs seized in Niger in current national languages

\begin{tabular}{llll}
\hline Families & Types & Name in Zerma & Name in Haoussa \\
\hline AMP & Amphetamines & - & - \\
BZE or BZO & Diazepam & Mimisso, D-5, D-10 & Hana-kowna \\
COC & Cocaïne & - & Hoda-Ibliss \\
THC & Cannabis, Crack & Soubou & Taba, Ganga, Kiff \\
MOP, MOR or OPI & Ephedrine, Metamphetamines & - & Es-Sidy \\
MTD or MTE & Tramadol, Heroïne & Dongo, Tché-berro & Tramol \\
\hline
\end{tabular}

\subsection{Seizures and drug use by age group and gender}

In Niger according to figure 4 many of drugs users are young with 59 percentage and the age bracket between 18 and 29; after this the following is the age bracket between 30 and 39. The old (more than 40 include) and the Youngers (less than 18) are the least affected. This shows that there are more young people who are involved in the consumption and sale of drugs in Niger. One of the reason of consuming drugs is the crisis of juvenile originality. The percentage of drugs used by gender is $98 \%$ for men against $2 \%$ for women is represented in figure 7 and the number users drugs fall from the years of 2014 to 2015 and increase in 2016. Girls are less affected than boys are because it is cultural. 


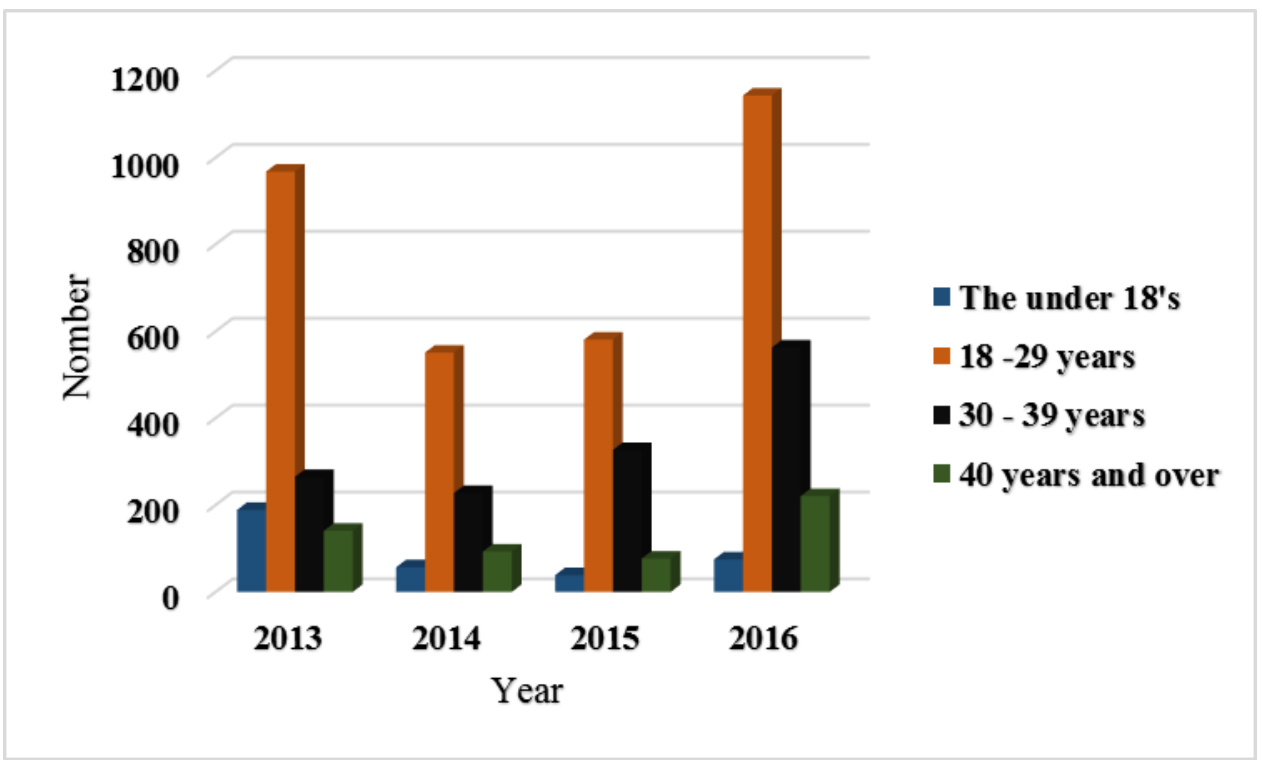

Figure 4: drugs use by age group from 2013 to 2016 in Niger

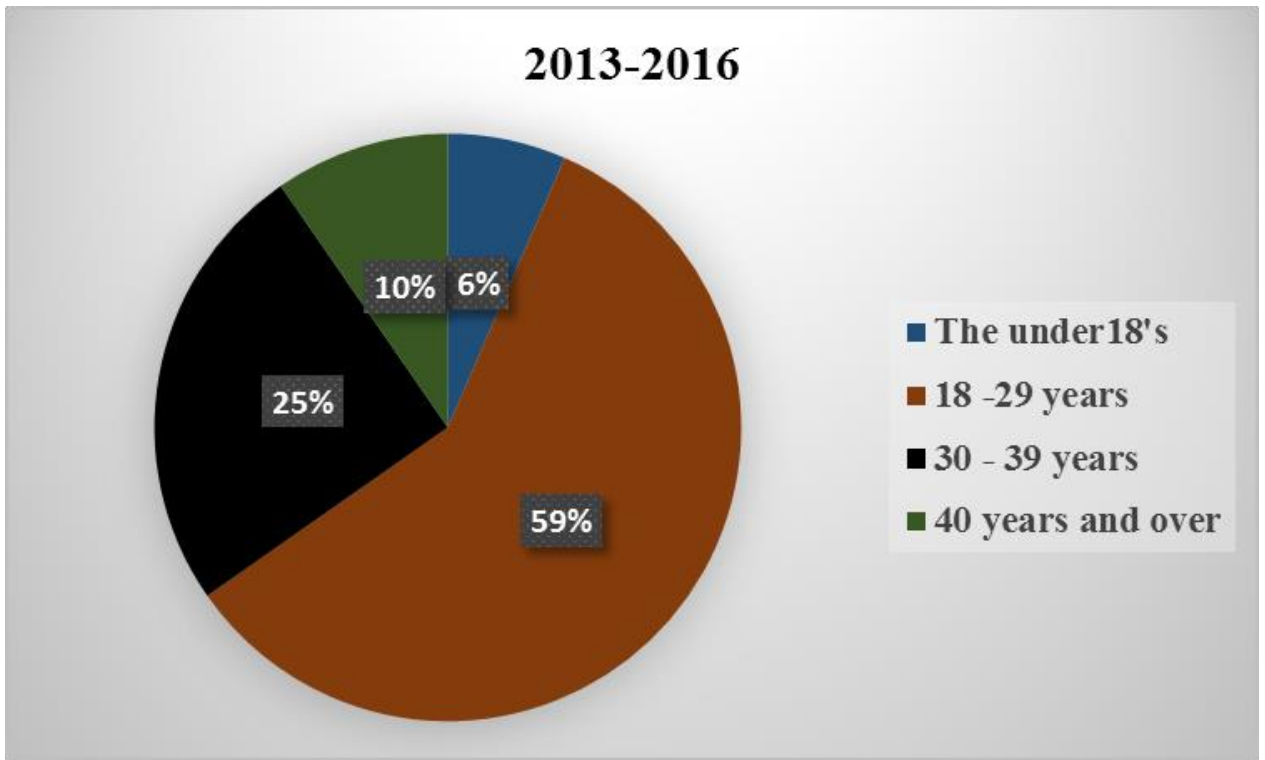

Figure 5: Percentage distribution of drugs seized by age group 


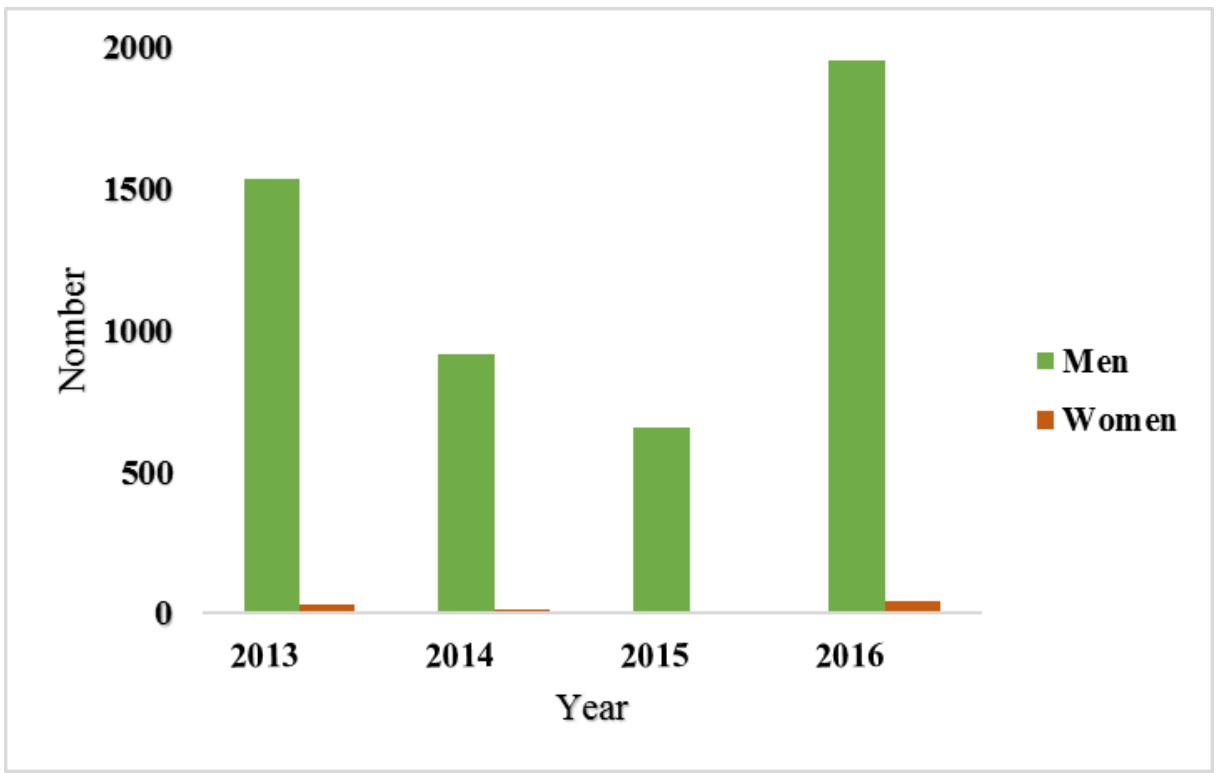

Figure 6: Distribution of drug use by gender

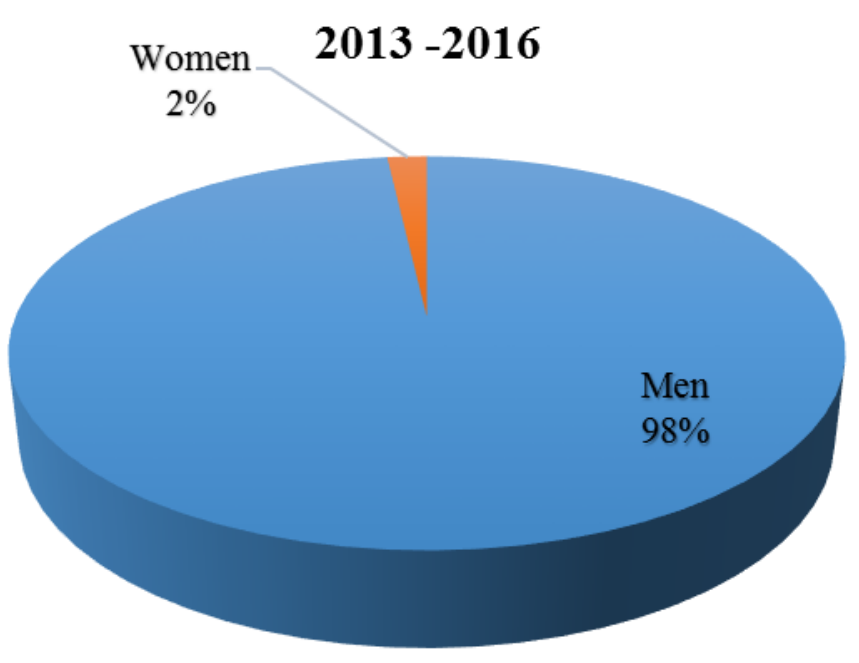

Figure 7: Percentage distribution of drugs seized by gender

\section{Conclusions}

In this survey, four (4) drugs out of nine (9) drug are the most used in Niger. $98 \%$ of these users drugs are men and they are in the age bracket from 18 to 39 in Niger. The most affected neighborhoods in Niamey is the commune $\mathrm{V}$ with provenances of limited country (Benin, Burkina Faso, Ivory Coast, Mali and Togo).

\section{Acknowledgements}

The authors are very thankful to:

The National Gendarmerie of Niamey,

The University (U A M) of Niamey;

The Central Office of damaging Trafficking drugs (OCRTIS) of Niger;

The Law Ministry of Niamey; 
The public prosecutor at a tribunal de Grande instance (TGI/HS) of Niamey.

\section{References}

[1] Basavaraju Thejur Jayadeva and Praveen Panchaksharimath, January 2016, A retrospective study on drug utilization in patients with acute exacerbation of bronchial asthma in adults at a tertiary teaching hospital in Bengaluru, pages 19-22.

[2] ONUDC, Rapport mondial sur les drogues $2015 ; 40$ p.

[3] Bawa et Yacouba Seyni, 2016; les drogues et leurs conséquences, 10 et 21 Diapositives ; D.D.2. 9

[4] ONUDC, Rapport mondial sur les drogues 2015, Volume 1,15p. ; http://www.unodc.org pp. 7 et 15

[5] Gendarmerie Royale du Canada ,2018, Tableau descriptif des drogues; 2 pages

[6] UNODC, Rapport mondial sur les drogues 2012, pp.11 et 13

[7] Gilles Landry, 2010, les drogues, 40 pages, pages 2-10.

[8] Gendarmerie Royale du Canada, 2015.

[9] Santé - Secourisme, 2013, le Figaro, La consommation de drogues en France et en Europe consulté sur http://sante.lefigaro.fr/social/sante-publique/consommation-drogues-franceeurope/consommation-drogues-france-europe consulté le 07/07/2017.

[10] ONUDC, Rapport mondial sur les drogues 2016, 16 pages, page 5.

[11] ONUDC, résumé analytique, conclusions et incidences stratégique, 2017; 36 pages, p. 9.

[12] Jean-Paul Deler et coll., 2003, Le bassin caraïbe: interface et relais entre production et consommation de drogues, 20 p., page 18.

[13] Chavanne, 2012, La drogue en Amérique Latine au XXème siècle, 18p.

[14] UNODC, Rapport mondial sur les drogues 2004, p. 41, 224p. ; http://www.unodc.org consulté le 26/08/2016 à $17 \mathrm{~h} 05 \mathrm{mn}$

[15] UNODC, Rapport mondial sur les drogues, 2010, résumé analytique 31p. p.12, http://www.unodc.org consulté le 26/08/2016 à 17h05mn.

[16] Institut Espagnol d'Études Stratégiques (IEEE) et Institut Militaire de Documentation de l'Évaluation et Prospective (IMDEP), 2013, Terrorisme et trafic de drogues en l'Afrique subsaharienne, 79 pages ; p.2.

[17] Isidore S. Obot, 2012, La consommation de drogues et ses effets sur les jeunes en afrique de l'ouest 9p., pp 4 à 6

[18] Observatoire Géopolitique des Drogues, 1994, La consommation de drogues et ses effets sur les jeunes en Afrique de l'ouest, 2012,9p. pages 6 le 15/10/2016 à 17h37mn

[19] Pascal Le Pautremat, 2013, Drogue au Sahel, http:// www.slate.fr/ consulté le 03/07/2016 à $21 \mathrm{~h} 53^{\prime}$

[20] Georges Berghezan, 2012, Groupe de Recherche et d'Information sur la Paix et la Sécurité, 8 pages, page 5 .

[21] Le trafic de drogue prend des proportions inquiétantes au Niger, www.actuniger.com le 18/10/2016 à 15h33mn, 27 Juin 2003 23:26:00

[22] Office Central de Répression de Traffic Illicite des Stupéfiants, 2013-2016, Statistiques Nationales des saisies de drogues, 11 pages.

[23] Seini Seydou Zakaria Publié dans Société \& Culture, Niger www.nigerinfo.com le $18 / 10 / 2016$ à $15 \mathrm{~h} 26 \mathrm{mn}$

[24] Sophie, 27 juin 2013, Société \& Culture article; www.Nigerdepeches.com le 15/10 2016 à $13 \mathrm{~h} 25 \mathrm{mn}$.

[25] Maxime Lambert, le 09 mai 2010 Les méthodes de dépistages des drogues, 
[26] Peter Jatlow et M.D., The Yale Journal of Biology and Medicine 61 (1988) 105-113, Cocaine: Analysis, Pharmacokineties, and Metabolic Disposition.

[27] Sabine Cohen et coll. Annales de Toxicologie Analytique, Vol. XV, $n^{\circ} 4,2004$, Intoxication volontaire par une tisane de feuilles de Datura, pp287-291.

[28] Ryder and coll., 2000, Quantitative analysis of cocaine in solid mixtures using Raman spectroscopy and chemometric methods, 12 pages.

[29] Michael Schiffer, Hair Analysis for Cocaine: The Requirement for Effective wash Procedures and Effects of Drug Concentration and Hair Porosity in Contamination and Decontamination, Journal of Analytical Technology, Vol. 29. July/August 2005, P 319-326.

[30] Kenichi Takaichi Direct extraction of benzodiazepine metabolite with supercritical fluid from whole blood, National Research Institute of Police Science, Chiba, Japan, Problems of Forensic Sciences, vol. XLIII, 2000, 263-274, Received 9 September 1999; accepted 16 May 2000, 12 pages.

[31] Bilal Yilmaz and Ali Fuat Erdem, Simultaneous Determination of Tramadol and its Metabolite in Human Urine by the Gas Chromatography-Mass Spectrometry Method, Journal of Chromatographic Science 2015;53:1037-1043 doi:10.1093/chromsci/bmu214 Advance Access publication January 22, 2015,7pages.

[32] Y. Gaillard et coll., Toxicorama 1996, n², Identification et dosage de la benzoylecgonine, cocaïne, méthylecgonine-ester, codeine, morphine et 6-acétylmorphine dans le sang total, 6 pages.

[33] Camille Richeval and coll., Determination of opiates, cocaine, amphetamine derivatives, and their metabolites in whole blood by solid-phase extraction and ULPC/MS-MS, 8 pages

[34] Saeed Habibollahi, November 21, 2014, Determination of Tramadol by Dispersive LiquidLiquid Microextraction, Combined with GC-MS, Journal of Chromatographic Science 2015; 53: 655 - 661 doi:10.1093/chromsci/bmu118 Advanced Access publications, 7 pages.

[35] Mahado Ismael et al., $17^{\text {th }}$ October 2016, A diagnostic test for cocaine and benzoylecgonine in urine and oral fluid using portable mass spectrometry, $9 \mathrm{p}$.

[36] Edmond Bermus et Sidikou A. Hamidou. Le relief : Les atlas afrique jeune. Paris : éditions J.a.1981, 64 pages, ISBN 2-85258-151-1. 